\title{
Correction to: The emergent role of digital technologies in the context of humanitarian supply chains: a systematic literature review
}

\author{
Josip Marić ${ }^{1}$ (D) Carlos Galera-Zarco² $\cdot$ Marco Opazo-Basáez ${ }^{3}$ (D)
}

(c) Springer Science+Business Media, LLC, part of Springer Nature 2021

\section{Correction to: Annals of Operations Research https://doi.org/10.1007/s10479-021-04079-z}

This erratum is published as typesetter overlooked several corrections and proofing errors introduced.

Original article has been updated.

Publisher's Note Springer Nature remains neutral with regard to jurisdictional claims in published maps and institutional affiliations.

The original article can be found online at https://doi.org/10.1007/s10479-021-04079-z.

Josip Marić

jmaric@em-normandie.fr

1 Department of Supply Chain Management and Decision Sciences, EM Normandie, Laboratoire Metis, Paris, France

2 The Bartlett School, University College London, London, UK

3 Department of Management, Deusto Business School, University of Deusto, Bilbao, Spain 